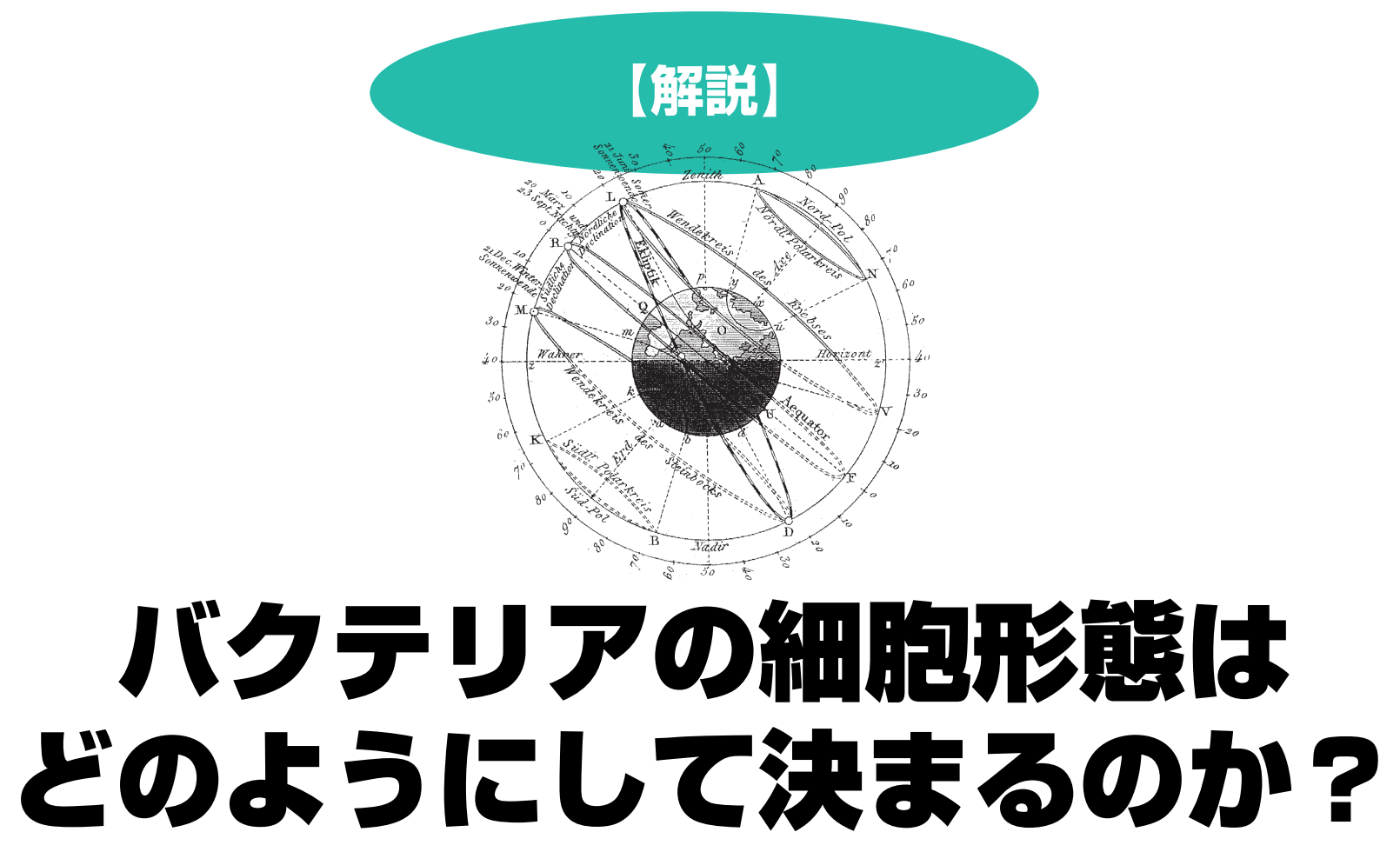

仁木宏典

細胞の形態はどのように決められているのか？これまでは まったく異なる仕組みであろうと思われていた原核生物で も，真核生物と同じアクチンファミリー細胞骨格因子によっ て細胞の形態が制御されていることが明らかになっている. さらに，新たな因子が見つかり，細胞長や細胞極性をどのよ うに制御しているのかという細胞の基本的な問題を原核生物 から分子レベルで問うことができるようになってきた.

バクテリア（細菌）を特徴づける要因の一つに細胞の 形態がある。丸い菌は球菌，これが連なったものは連鎖 球菌, らせん状に曲がったらせん菌, 長楕円形の桿菌と, 形態は細菌の判別に利用され, 種名や属名として種分類 の基準としても使用されている。これは, 細胞の形態が それぞれの種で固有であることによる，栄養状態によっ て細胞の寸法は変化するが，遺伝的にその形は保たれて いるということである. 単に脂質二重層の細胞膜だけで は，生育環境から受ける様々な機械的な応力により細胞 は変形し壊されてしまうだろう。しかし，多くのバクテ リアはペプチドグリカンという丈夫な層に細胞全体が覆 われており，機械的な強度を保っている。したがって， ペプチドグリカンの形がその細胞の形態をつくっている

Determination of Bacterial Rod Shape

Hironori NIKI, 国立遺伝学研究所/総合研究大学院大学遺伝学 専攻
ということになる，確かに，ペプチドグリカンがなくな ると桿菌は球形になる。

ペプチドグリカンの合成については，これまでに多く の研究の蓄積がある。ペニシリンに代表される多くの抗 生物質がペプチドグリカン合成のプロセスを標的とした ため，医学的に多くの人々の関心を引きつけてきたの だ。ただ，合成の過程については多くの知見が得られて いるが，なぜ形やその寸法が決まるかという点について は不明な点が多い，形態異常を示す多くの遺伝子変異株 も見つかってきていたが，形態を決める仕組みまで解明 するには至っていなかった。 この問題を大きく進展させ たのは，バクテリアの中にもアクチン様の細胞骨格性の タンパク質 MreB が存在しているという発見であった. 細胞内にらせん状の構造をとるバクテリアアクチン Mre B を足場としてペプチドグリカン合成が行なわれ， 細胞の形態や大きさを決めていると考えられるように なった. したがって，この MreBアアチンの細胞内での 配置を制御することが形態形成の制御につながると考え られる。最近，新たに見つかった形態形成の制御因子で ある $\operatorname{RodZ}$ は, 細胞骨格因子 MreB と相互作用しなが ら，細胞長の調節をしていることが明らかになってき た. 


\section{バクテリアの細胞壁, ペプチドグリカン}

植物, 菌類, バクテリア類はみな細胞壁をもっており, 細胞の形態維持に重要な役割を果たしている，それぞれ の細胞壁の構成は異なっており, 植物ではセルロース が，菌類ではグリカンやキチンが，そしてバクテリアで はグリカンが主要な成分となっている，バクテリア類, すなわち原核細胞では，グリカンとペプチドが結合して ペプチドグリカン層をつくる.

原核細胞の分類でよく使われるグラム陰性菌, グラム 陽性菌とは, グラム染色という化学的な染色をして顕微 鏡観察した際の染色の度合いで菌類を分類したものであ る.グラム染色はペプチドグリカンを染色するため, ペ プチドグリカンの構造を反映した分類基準となってい る.グラム陽性菌の代表格である枯草菌は細胞膜の外側 に多層からなるペプチドグリカン構造をもつ. 一方, グ ラム陰性菌の大腸菌は, 細胞膜と同じく脂質膜である外 膜の間に, グラム陽性菌に比べて薄いペプチドグリカン 層をもつ. また, ペプチドグリカン層と細胞内膜や細胞 外膜とはいろいろなタンパク質で構造的に一体化してい る.

ペプチドグリカン層は細胞全体を取り囲んでいる。 バ クテリアを界面活性剂で長時間煮て, タンパク質や脂質 を除いた後には, 細胞を取り囲んでいたペプチドグリカ ンが細胞の形態を保持したまま残っている．ペプチドグ リカン層は袋状の巨大な一分子を形成しており，これを 特にサキュルス (Saculus) と呼ぶ。サキュルスは細胞の 伸長や分裂の際には, 一部の分解を伴いながら, 新規の 合成を行なっているのである，では，その合成はどこで 起こり, どのような方向にグリカンの重合体は配置され ているのであろうか.

ペプチドグリカンは, $N$-アセチルムラミン酸と $N$-ア セチルグルコサミンが交互に直鎖状につながったグリカ ン重合体の縦糸が，短いペプチドの横糸により架橋され た構造である．細胞分裂面では細胞のくびれと同時に新 しい細胞壁ができるため, ペプチドグリカン合成が盛ん に起こっている．細胞伸長は細胞全体で起こっていると 考えられてきたが，枯草菌でペプチドグリカンの新規合 成の場をさらに詳細に見てみると, 細胞表層上にらせん 状に分布していることがわかった(1).このらせん状の分 布というのがバクテリアのアクチンタンパク質 MreB の分布と類似していたことから, MreBのらせん状の細 胞骨格のもとにペプチドグリカンの合成酵素が配置され ているのだろうと考えられている。 MreB はそもそも細 胞形態の異常を起こす変異体として見いだされており,
その欠損株では球形の細胞形態をとることが知られてい た.

\section{細胞骨格タンパク質 MreB の発見}

大腸菌は遺伝学的な研究材料として分子生物学の黎明 期から盛んに研究されてきた. 多くの遺伝子変異株が分 離されてきたが，その中には細胞形態に異常をきたすも のが数多く知られていた. 特に, 桿菌から球菌へと変わ る変異体は, 表現型が特徴的なことから数多く分離さ れ, その原因として複数の遺伝子の変異が見いだされて いる. ペプチドグリカンの合成酵素遺伝子群の変異もそ の一つであり，たとえば $p b p 2$ やその制御因子である $\operatorname{rod} A$ 遺伝子の変異では球形の細胞に変異する。一方, ペプチドグリカンの合成酵素以外の遺伝子で球形となる 遺伝子として mre 遺伝子群が, 和地らにより分離され報 告された ${ }^{(2)}$. 特に $m r e B$ 遺伝子は, アクチンタンパク質 の配列と相同性をもつ ATPase ファミリーのタンパク 質と予想されたが，これがバクテリアのアクチンである ことは後に証明された。

大腸菌 $m r e B$ 遺伝子は, 球菌には保存されていないも のの球形以外の複雑な形をした原核細胞を中心に広く保 存されている. 枯草菌には 3 種類の $m r e B$ 相同遺伝子が 見つかっている. オックスフォード大の Errington ら は, 枯草菌の $m r e B$ と $m b l$ 遺伝子を破壊してその機能を 調べ(3)，いずれの遺伝子もその破壊によって細胞の増殖 が低下することを見いだした．このような細胞を顕微鏡 で観察すると細胞形態が変化していた，本来なら，長方 形の桿菌であるはずの細胞が太短い形に， あるいは細胞 が伸長しねじれたような形になっていた，大腸菌のよう に球形にはならないものの細胞形態に異常が生じている ことは明らかだった，そして，驚くべきことは，これら のタンパク質が細胞内で重合し，らせん状に分布してい るという事実であった。蛍光タンパク質 GFP で標識し たタンパク質が細胞を取り巻くようならせんとして観察 されたのである。そこで, 細胞骨格性タンパク質のごと く細胞表層を取り巻き, その変異により細胞形態が異常 になることから，これらのタンパク質はバクテリアの細 胞骨格タンパク質と考えられた. これはタンパク質の結 晶構造からも証明され, 原核生物にアクチン様の細胞骨 格性タンパク質が存在することが明らかになった(4). 事 実，バクテリアの MreB はアクチン特有の 4 つのドメイ ンからなる球状タンパク質構造をもち, その中心部に ATP 結合部位が位置する.

枯草菌には $m r e B$ の相同遺伝子は 3 つあり, それらは 


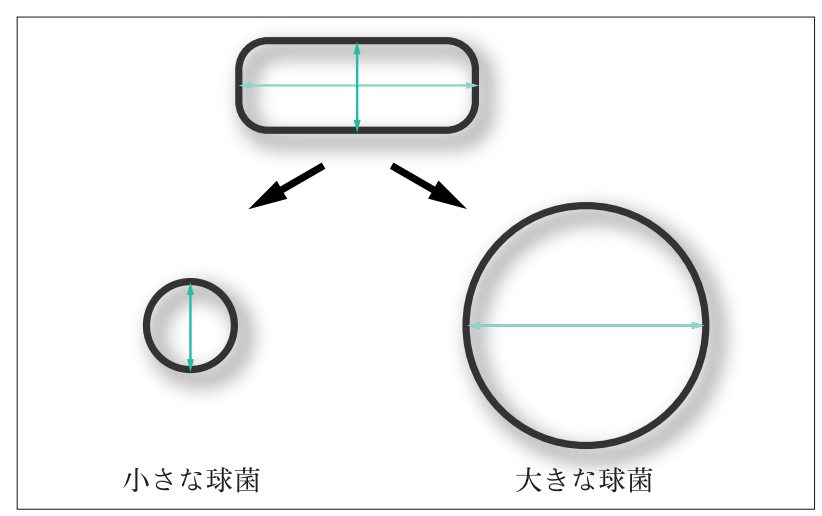

図 1 - 桿菌のサイズを決める 2 つの軸

桿菌は細胞幅 (短軸) と細胞長 (長軸) の 2 つの軸で細胞形態 が決まる。 その一方がなくなれば，細胞は残った軸の長さで規 定された球菌となるであろう.

細胞のサイズの長軸方向と短軸方向という異なった制御 にそれぞれ機能が分かれているのかもしれない（図1).

また，それぞれの破壊株は細胞形態の異常という表現型 を示すものの, 培地中に $\mathrm{Mg}^{2+}$ を加えるだけで再び桿菌 に復帰することから，これらの遺伝子産物の間で機能的 な重複があり，その代償機能が $\mathrm{Mg}^{2+}$ を加えることで増 強されているのであろう(5). しかし，大腸菌には 1 種類 の $m r e B$ 遺伝子しかなく, この 1 種類の $\mathrm{MreB}$ で細胞の 長軸方向と短軸方向の制御を同時に行なっているのかど うか，この点ははっきりしていない，いずれにせよ，バ クテリアの中でアクチン様の細胞骨格因子が細胞形態の 制御に機能していることは, 現在ではほぼ確かになって いる。

バクテリアでは $\mathrm{MreB}$ 以外にもアクチン様タンパク 質が見つかっている. 多剤耐性プラスミドである $\mathrm{R}$ 因子 の分配遺伝子である ParM がそれである(6,7). ParM タン パク質は細胞内で重合してフィラメントをつくる，その 両端に R プラスミド DNA が結合しており, ParM フィ ラメントの伸長とともに R プラスミドが娘細胞に分配 されるという，真核細胞の分裂装置に驚くほどよく似た 仕組みで DNA 分配を行なっている．このことから，バ クテリアの染色体の分配は MreB によるものではない かと考えられ，これを示唆するような結果がCaulobacterで報告された ${ }^{(8)}$. しかし最近になって, この結果は, 広く一般化できるものではないといわれている( ${ }^{(9)}$.した がって, MreBがバクテリア染色体の分配に直接関与し ていることを支持する明確な根拠はない. MreB の機能 として重要なのは, 細胞の極性を決めることではないか と考えられる. 細胞の極性は細胞の伸長方向を決め, ま た細胞形態だけでなく染色体分配の方向も決めることに なるため, 間接的にせよ染色体分配の過程でも重要であ
ることはいうまでもない.

\section{新規形態形成の制御遺伝子 rod $Z$ の発見}

これまで形態形成の変異遺伝子は, 細胞増殖に強く影 響を及ぼす必須遺伝子として見いだされ分離されてき た。 また，長年にわたって多くの変異体が分離されてき たので，形態形成に関わる重要な遺伝子は調べつくされ たと思われていた。 ところが， 2008 年から 2009 年にか けて, 必須遺伝子ではないもののバクテリアの形態形成 に関与する新規遺伝子 rodZ の発見が次々と 3 つの研究 グループから独立に報告された ${ }^{(10 \sim 12)}$.

細胞形態形成に関係する $m r e B$ 遺伝子が久損すると生 育の阻害が起こるが，この生育阻害は細胞分裂の最重要 因子であるバクテリアチューブリン FtsZ の発現を上げ ることで抑制される. Pite de Boer らは, mreB 遺伝子 以外にも FtsZ の発現上昇によって生育が改善されるよ うな変異があるのではないかと考え, 大腸菌変異株スク リーニングを行なった結果, rodZ 遺伝子を見いだし

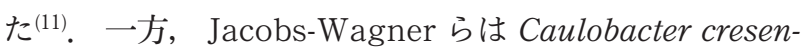
tous の細胞形態異常を示す変異株を調へ，その原因遺伝 子に相同の遺伝子が大腸菌にも保存されていて細胞形態 の異常をひき起こすことに気づいた(12)。これが rodZ 遺 伝子であった。 そして, 筆者らのグループは, 大腸菌の 遺伝子破壊変異株のコレクションから, 桿菌が球状にな るという形態異常の変異株を見いだし rod $Z$ 遺伝子を見 つけ出したのである(10) (図 2).

KEIO コレクションは, 奈良先端科学技術大学院大学 の森グループにより作製された大腸菌遺伝子の網羅的な 遺伝子破壊株のライブラリーである ${ }^{(13)}$. 大腸菌ゲノムか ら予想される遺伝子のうち, 破壊可能なものをほぼすべ て系統的に薬剂耐性遺伝子と置き換え, 破壊したのであ る，3,909 株から成る KEIO コレクションは，スクリー ニングなどさまざま用途に使われている。ナショナル バイオリソースプロジェクト (NBRP) 原核生物遺伝資源 事業（国立遺伝学研究所）では, KEIO コレクションの 保存と分譲を行なっており，これまでにすでに 104 セッ トの KEIO コレクションを国内外に送り出している. 筆 者らのグループでは, KEIO コレクション 3,909 株すべ ての細胞形態の観察を顕微鏡下で行なった。 そして, 唯 一, 球形の形態変異を示す rod $Z$ 遺伝変異株を見いだし たのである。いずれのグループの報告でも，遺伝子欠損 では細胞形態の異常が認められ, 桿菌から球形になる新 規の形態形成の関連因子と結論した。 

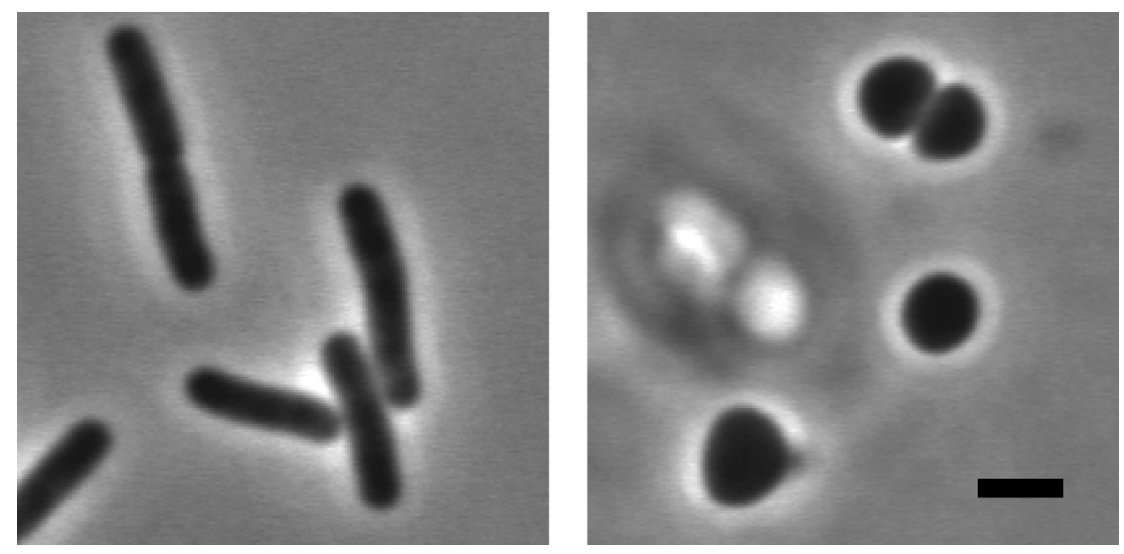

図 2・大腸菌 RodZ 変異株の細胞形態 対数増殖期の細胞を位相差顕微鏡で観察. 桿菌の野生株（左）が，rod $Z$ 遺伝子破壊 株では球あるいは楕円に形態を変える (右).スケールバーは $1 \mu \mathrm{m}$

(A)

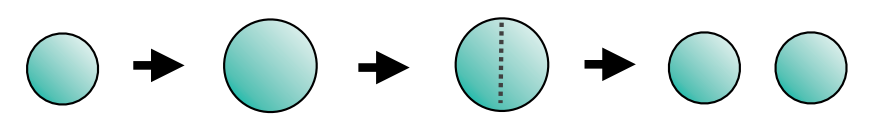

(B)

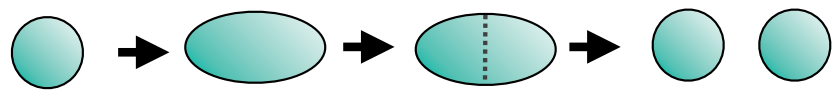

\section{形態形成での RodZ の機能}

では，rodZ 遺伝子はどのような機能を経て細胞の形 態形成に関与しているのであろうか，筆者らは， RodZ 変異株の球形の細胞が，これまでに知られていた $m r e B$ や rodA の球形の変異細胞とはその大きさが異なってい ることに気がついた，小さいのである，細胞の大きさを 測定して確かめてみると, 確かに同じ球形であってもそ の大きさには有意な差があった，桿菌の大きさは, 細胞 長といわれる長軸方向での制御と細胞幅という短軸方向 の 2 つの因子で形態が決まると単純化できる（図 1). rodZ 遺伝子変異株では, 長軸方向での制御ができない, すなわち, 細胞の伸長が十分にできない変異と考える と，この細胞の大きさの違いを説明できるように思われ た。 そして, 実験から rodZ 遺伝子変異株では長軸方向 への伸長ができなくなっていることが確認できた.

まず, $\operatorname{rodZ}$ 遺伝子の発現をアラビノース誘導プロ モーターの制御の下に置き, 発現を抑制した後に桿菌か ら球状の菌へと変わる様子を調べた。 その結果, 細胞の 幅は一定であったが, 細胞長が短くなって, 最後には球 形になった. 反対に, rod $Z$ 遺伝子の発現を抑制した状態 から発現を誘導した場合, 球形の細胞の一端が突起とし て現われ，これを先端として伸び始める．先のやや細い 伸長した細胞となり, これが二分裂して元の桿菌の形態 に近づいていく．また， RodZタンパク質を野生株の中
で過剩発現させると, 細胞幅は変わらないが, 細胞は通 常より長くなる。つまり, 細胞長の制御ができるのであ る.

これらの表現型から, rodZ 変異株の中では長軸方向 への伸長が十分に起こっていないと考えられた。では， この細胞ではどのようにして細胞体積を増やし，二分裂 しているのであろう。 バクテリアの仲間には球菌も数多 く知られている，その球菌も細胞分裂の様式で 2 つの夕 イプに分かれる ${ }^{(14)}$ (図 3)。一つは, 細胞全体の体積が一 様に増加して球形のまま二分裂するもので, 分裂後に分 裂面が飛び出して全体が球形に戻る. Staphylococcus 菌 類や黄色ブドウ球菌がこれにあたる。他方, 球菌が横方 向に伸長して楕円となり，二分裂するものがある．分裂 の後には球菌へと形を戻す. Streptococcus 菌類がこれ に相当する. $\operatorname{rod} Z$ 変異株は後者の分裂の仕方をしてい る．また，数回にわたり分裂を連続して観察すると，常 に伸長方向と分裂の方向は一定である。これは, rodZ変 異の球状細胞の中で, 細胞の極性が一定に保たれている ことを意味している.

\section{極からだけなる細胞か？}

桿菌の細胞形態は, 幾何学的に単純化し円柱（シリン ダー）とその両端を塞ぐ半球（キャップ）からできてい るとモデル化される (図 4)。シリンダー部分が伸長し, 


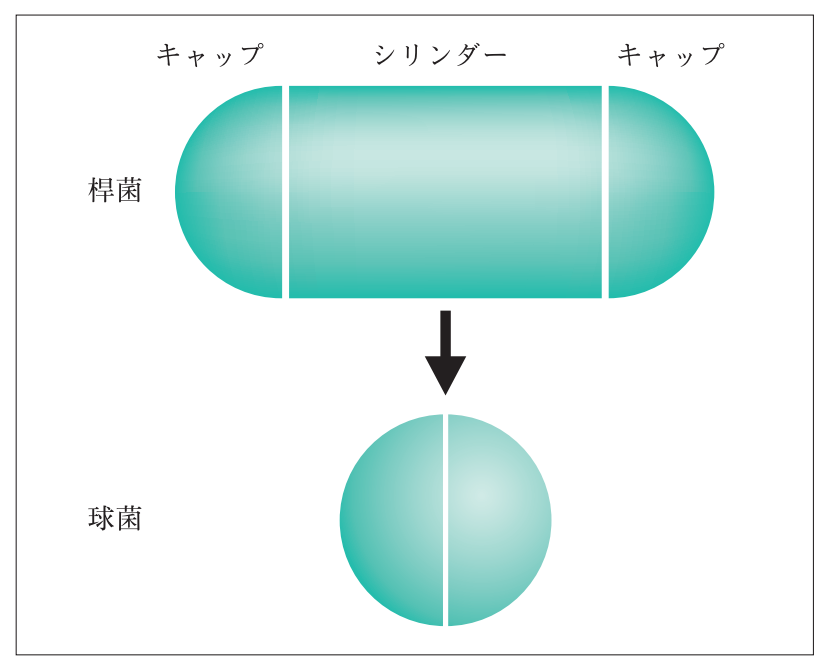

\section{図 4 - 桿菌の細胞形態の幾何学的なモデル}

桿菌は円柱のシリンダーの両端に, 半球のキャップがついたも のと単純化される。このシリンダー部分がなくなれば，キャッ プからなる球菌ができる.

中央部分で分裂する。 そして分裂面が，外側に膨らんで キャップとなる。 キャップの部分は, 細胞分裂のなれの 果てであるとしばしばいわれるが, 桿菌にとって重要な 部分である。この部分に局在するタンパク質屯数多く知 られている。 その中にはバクテリアの走化性の受容体夕 ンパク質Tarがある. Tar を蛍光タンパク質 GFP で標 識して大腸菌で発現させると, 細胞の両極がきれいに蛍 光で染まる(15).

rodZ 変異の球状細胞は, 桿菌が伸長しなくなった細 胞であると考えられる.つまり, シリンダーの部分が極 端に短いかもしくはなくなっているのである。 そうする と, この球状細胞はキャップからだけしかできていない ということになる。実際に, GFP 標識したTar タンパ ク質の細胞内分布を観察してみると, 球状の細胞全体に 一様に蛍光が見られ，キャップからできていることと一 致する (塩見, 仁木, 未発表). 他方, mreB 欠損による 球状の細胞では, Tar タンパク質はパッチ状に細胞の表 層全体に分布しており，まったく異なっている。これは, 細胞の極が複数できたことによると考えられる.

\section{$\operatorname{RodZ}$ も細胞骨格タンパク質}

これまで, 細胞の形態は細胞骨格タンパク質である $m r e B$ によって制御されると考えてきた. RodZタンパ ク質は $\mathrm{MreB}$ とどのような機能的な関係をもっている のであろうか? RodZタンパク質のアミノ酸配列か ら, 膜貫通ドメインが 1 個所見つかり, 細胞分画すると 膜タンパク質の画分から回収され，細胞膜に局在してい

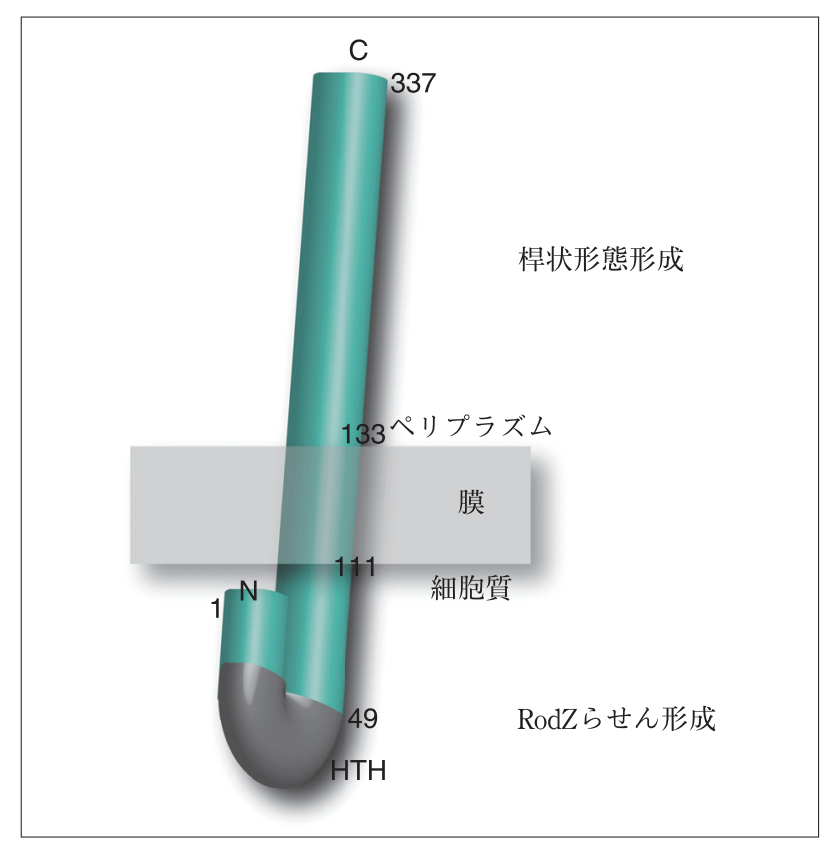

\section{図 5 - RodZ タンパク質の機能のモデル}

RodZタンパク質は細胞膜に組み込まれて存在する。番号はア ミノ酸残基を示す. 1 111 までの細胞質側はヘッリクスーター ンーヘリックス (HTH) の構造をむち, 主に細胞内のらせん構造の 形成に寄与する。 ペリプラズムの領域は桿状の細胞形態に必須 である.

た。 その配向を調べると， $\mathrm{N}$ 末端部分が細胞質側に， C 末端側が細胞外, すなわちペリプラズム側に突き出てい た（図 5). GFP 標識した RodZ を使って, 細胞内での夕 ンパク質の分布を観察してみると, 蛍光は細胞膜上に分 布していた，さらに，高解像度で細胞内の分布を立体的 に調べてみると, 細胞表層をらせん状に取り巻いている ことがわかった。この分布様式はバクテリアアクチンで ある MreB と類似していた。実際，2色の蛍光タンパク 質を使って観察した RodZ と MreB の細胞内分布はほ ぼ同じであった。

MreB のらせん構造の上に RodZ が集まってきている ことが十分に考えられたので, RodZのらせん構造に対 する MreB の影響をみた，MreB の脱重合を起こす化合 物 $\mathrm{A} 22^{(16)}$ を添加後数時間すると, 細胞に見られた $\mathrm{MreB}$ のらせん構造は消失し, MreB-GFP の蛍光は細胞全体 に広がる。しかし，このような細胞内でも RodZ は依然 としてらせん構造を保持していた. また, MreB の欠損 株でも RodZ の纎維状の分布が細胞表層に観察できる が，細胞全体を取り巻くらせん構造とはならない。 $\operatorname{RodZ}$ は MreB とは独立に重合体を形成できるが, 桿菌 でのきれいならせん状の分布には MreB が寄与してい るのであろう。 RodZ の機能ドメインを調べた結果によ れば, 細胞質側にある $\mathrm{N}$ 末端のドメインが $\operatorname{RodZ}$ のら 


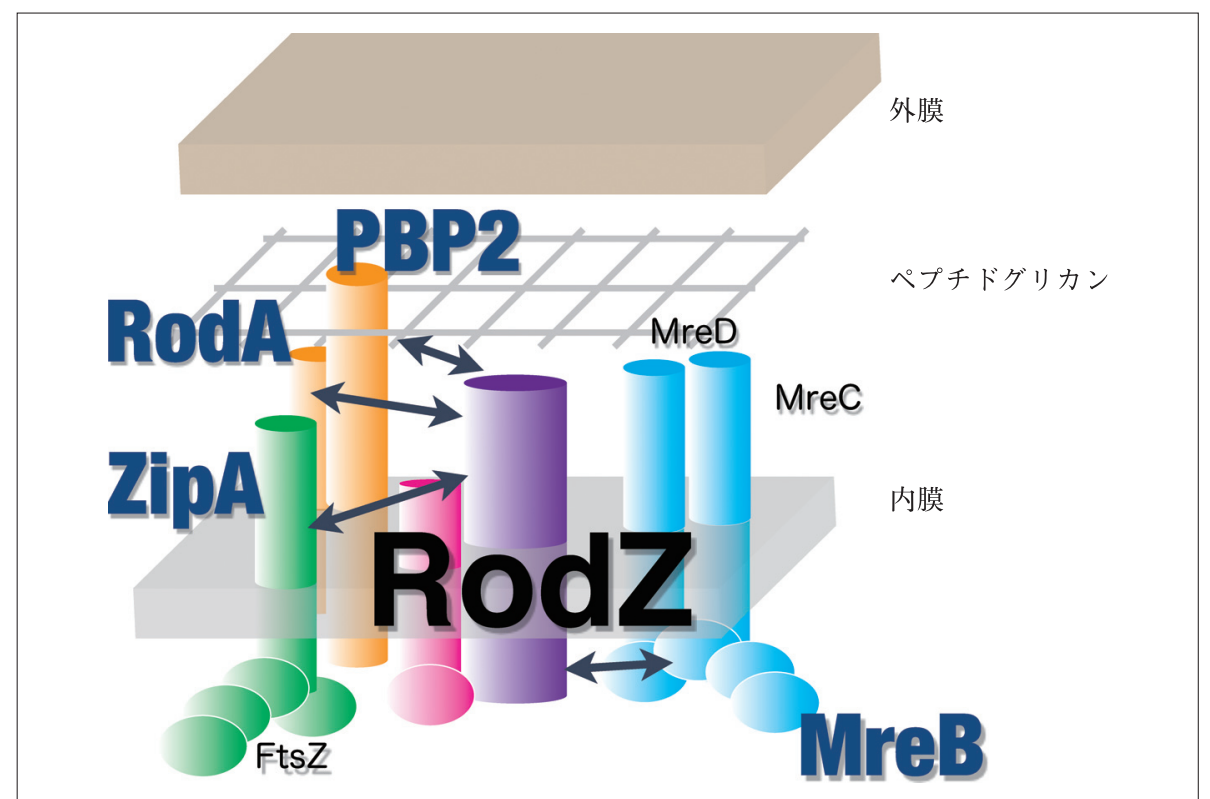

図 6 - RodZ タンパク質とその他の形態形成関係因子の機能的な相関
バクテリアアクチンは膜タンパク質 である MreC, MreDによって細胞 膜の内側に重合し，らせんを形成す る. シリンダー部分, すなわち横方 向への伸長の主要なペプチドグリカ ン合成酵素である PBP 2 は RodA などの制御を受けながら機能する。 細胞分裂を担うバクテリアチューブ リンである FtsZ の膜への局在には ZipA が働いている. RodZタンパ ク質は，これらの因子を制御し，横 方向のペプチドグリカンの合成を調 節している.
せん構造の維持に必要である。このドメイン内には DNA 結合モチーフとしてよく知られているヘリックスターン-ヘリック $(\mathrm{HTH})$ モチーフがある. HTH モチー フはタンパク質どうしの結合活性を示す例も知られてい るので，この領域で MreB と結合していることも考えら れる。しかし不思議なことに，桿菌の細胞形態には必ず しもこの $\mathrm{N}$ 末端のドメインは必要なく, 膜ドメインと $\mathrm{C}$ 末端のドメインのみでも形態を維持できる.

\section{細胞壁合成と RodZ}

$\mathrm{C}$ 末端のドメインはペプチドグリカン層の側にあるの で，ペプチドグリカンの合成酵素群と相互作用している ことが十分に考えられる。事実， C 末端のドメインのみ を多量に発現させると細胞形態に異常がみられ, ペプチ ドグリカンの合成に影響を与える。 $\operatorname{rod} Z$ 欠損細胞は, 球 形になりながらも増殖するのであるが，その速度が低下 する. 球形になったこの変異細胞内の代謝活性は劇的に 変化しており, 電子伝達系の遺伝子が欠損した変異細胞 と同じような代謝活性のプロファイルを示す(17)。これ は，シリンダー部分を欠損し球形になったため, 細胞表 層にある各種のトランスポーターや電子伝達系のタンパ ク質の局在が著しく乱され, 細胞内のさまざまな代謝活 性に影響がでたと考えられる。細胞形態の代謝への影響 は，増殖速度が低下している変異細胞から，再び増殖が 野生型並みに回復したものを比較的に簡単に分離するこ とができ，このとき同時に細胞の形態が桿菌または楕円
菌に回復していたことからも示唆された（塩見，仁木， 未発表)。

さて，ではどのような遺伝子の変異が，増殖速度を回 復させ, $\operatorname{rod} Z$ 遺伝子が欠失しているにもかかわらず細 胞形態を桿菌に戻すことができるのであろうか.これま での遺伝学の手法であれば，変異遺伝子 1 つを決めるに もかなりの時間を要していた. 近年の次世代シーケン サーといわれる大量 DNA 配列決定機器の発達で, 大腸 菌の全ゲノム $4.6 \mathrm{Mb}$ であれば，全ゲノム配列を調べ変 異部位を特定することが可能となっている，実際に，複 数の抑制変異株についてその変異遺伝子を決めたとこ ろ，ペプチドグリカン合成酵素 PBP2，その制御因子 $\operatorname{Rod} \mathrm{A}$ ，さらにバクテリアアクチン MreB の遺伝子に変 異が見いだされた。また，さらに細胞分裂の際に FtsZ 亡相互作用する因子である $z i p A$ 遺伝子にも変異が見い だされた。現在，これらの遺伝子の抑制のメカニズムに ついてさらに研究を進めている.

$\operatorname{rod} Z$ 遺伝子が欠失しても新たな遺伝子変異によって 桿状の細胞形態に復帰できることから，細胞形態を維持 するためのペプチドグリカンの合成酵素やその調節因子 があれば， rodZ 遺伝子がなくてもなんとか桿菌の形態 を維持できるのである. $\operatorname{Rod} Z$ はペプチドグリカンの合 成酵素や調節因子の働きを制御することで，長軸方向へ の細胞伸長を調節しているものと考えている（図 6). 


\section{おわりに}

$\operatorname{Rod} Z$ がその C 末端側でペプチドグリカンの合成酵素 に作用していることがわかってきた。 一方, 細胞質内の $\mathrm{N}$ 末端側の機能はなんであろうか? らせん状の構造 をとるということにはどのような意味があるのであろう か. 細胞の長さは栄養条件によって変わる. 貧栄養条件 下より富栄養条件下のほうが細胞は長くなる。 また，定 常期に入り細胞の増殖が停止すると, 細胞長は短くな る. 栄養条件などの要因により細胞内の状態が変わった とき，これを感知して細胞長を制御しているとしたら， $\mathrm{N}$ 末端側のドメインはそのための中心的な役割を担っ ているであろう. また, $\operatorname{Rod} Z$ は古細菌にはなく, 真正細 菌には非常に広く保存されており, 起源の古い遺伝子の 一つであることがうかがい知れる ${ }^{(12)}$. 桿菌の形成に重要 なことはもちろんであるが, 球菌である Streptococcus, Staphylococcus にも保存されており, 細胞形態の維持の ためのより広範囲な機能をもっていると思われる。これ らの球菌での研究が進めば, $\operatorname{Rod} Z$ の本来の機能がさら に鮮明になってくるであろう。

謝辞：本総説に執筆するにあたり，共同研究者の国立遺伝学研究所 博 士研究員, 塩見大輔博士に深く感謝します.
文献

1) R. A. Daniel \& J. Errington: Cell, 113, 767 (2003).

2) M. Wachi \& M. Matsuhashi:J. Bacteriol., 171, 3123 (1989).

3) L. J. Jones, R. Carballido-Lopez \& J. Errington : Cell, 104, 913 (2001).

4) F. van den Ent, L. A. Amos \& J. Lowe: Nature, 413, 39 (2001).

5) M. Leaver \& J. Errington:Mol. Microbiol., 57, 1196 (2005).

6) J. Moller-Jensen, R. B. Jensen, J. Lowe \& K. Gerdes : EMBO J., 21, 3119 (2002)

7) F. van den Ent, J. Moller-Jensen, L. A. Amos, K. Gerdes \& J. Lowe : EMBO J., 21, 6935 (2002).

8) Z. Gitai, N. A. Dye, A. Reisenauer, M. Wachi \& L. Shapiro: Cell, 120, 329 (2005).

9) E. Toro, S. H. Hong, H. H. McAdams \& L. Shapiro : Proc. Natl. Acad. Sci. USA, 105, 15435 (2008).

10) D. Shiomi, M. Sakai \& H. Niki : EMBO J., 27, 3081 (2008).

11) F. O. Bendezu, C. A. Hale, T. G. Bernhardt \& P. A. de Boer : EMBO J., 28, 193 (2009).

12) S. A. Alyahya, R. Alexander, T. Costa, A. O. Henriques, T. Emonet \& C. Jacobs-Wagner: Proc. Natl. Acad. Sci. USA, 106, 1239 (2009).

13) T. Baba, T. Ara, M. Hasegawa, Y. Takai, Y. Okumura, Baba, M. K. A. Datsenko, M.Tomita, B. L. Wanner \& H. Mori : Mol. Syst. Biol., 2, 20060008 (2006).

14) A. Zapun, T. Vernet \& M. G. Pinho: FEMS Microbiol. Rev., 32, 345 (2008).

15) D. Shiomi, M. Yoshimoto, M. Homma \& I. Kawagishi : Mol. Microbiol., 60, 894 (2006).

16) N. Iwai, K. Nagai \& M. Wachi : Biosci. Biotechnol. Biochem., 66, 2658 (2002).

17) M. Ito, T. Baba \& H. Mori : Metab. Eng., 7, 318 (2005). 